\title{
Social-Environmental Atlas of the Lençóis Maranhenses area in Northeastern Brazil. First results of a methodological approach.
}

\author{
Reinaldo Paul Pérez Machado $^{\mathrm{a},}$, Ulisses Denache Vieira Souza ${ }^{\mathrm{b}}$ \\ ${ }^{a}$ Department of Geography, University of São Paulo.Brazil, rpmgis@usp.br \\ ${ }^{b}$ University College, Federal University of Maranhão. Brazil, ulissesdenache@usp.br \\ * Corresponding author
}

Keywords: Special Regional Atlas; Local communities; Cybercartography; Applied Geotechnologies; National Parks and protected areas.

Abstract:

For a long time Lençóis Maranhenses region in Northeastern Brazil, has been calling attention for being an area of extreme contrasts, not only under the physical-geographical and climatic point-of-view, but also because of the great contradictions and social conflicts that can be found there. A big part of the territory has been officially declared a National Park on June 2nd, 1981 (BRASIL, 1981), although the Region of Lençóis and Pequenos Lençóis (Little Lençóis) extends beyond the area protected by the National Park (TSUJI, 2002). Communities established inside the National Park are supplied with electricity, while others, just a few kilometres away; lack this resource, even being located within the official perimeter (SOUZA, 2007). The consequences of these expressions of spatial injustice can be considered terrible: severe health problems, serious conflicts between tourism activities and the traditional ways of production, among others.

The region (Figure 1) has never been object of a multidisciplinary and organized study in the form of an atlas, in spite of being very popular and attractive under the touristic point-of-view. For this reason, the research intends to elaborate the Social-Environmental Atlas of Lençóis Maranhenses in its wholeness, and, in a later stage, proceed with its publication in paper and digital form. This atlas will have about 200 pages and, initially, 13 sections have been defined. In view of its thematic and territorial content, it can be classified in the category of special regional atlas (SALITCHEV, 1979).

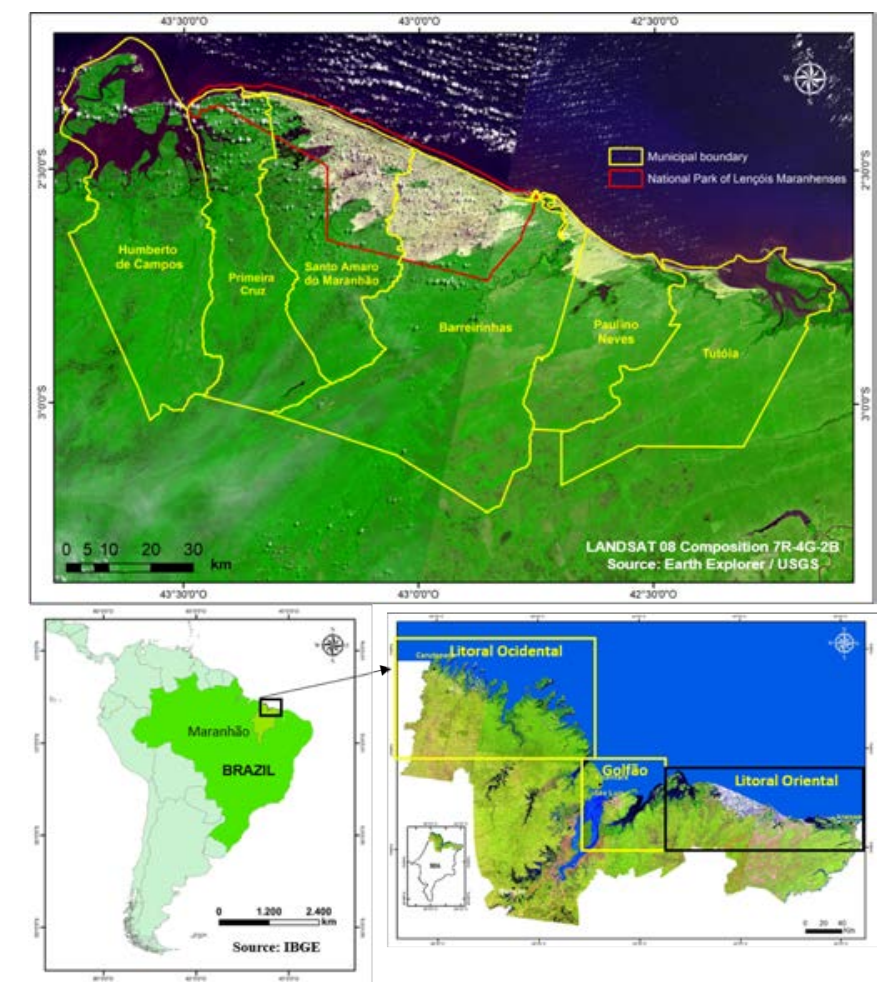

Figure 1. Focus area of the Social-environmental Atlas. Source: Earth Explorer and IBGE. 
Therefore, the proposed atlas will focus not only on the National Park but also on its surroundings. Thus, we intend to study all the geographical space, categories of land use and forms of occupation by society as a whole, with emphasis on the traditional communities which dwell in the area. This region is characterized by an environment unfit for most farming crops, not only because of its sandy soil, but also because of moving dunes and of the hydric regime, sometimes with rain in excess, other times with long drought periods (Figure 2). All these factors, associated to the difficult access to the area, contribute to a most vulnerable population, causing an obvious influence on their ways of life. Nevertheless, people who live there have found ways to produce and provide for themselves. Fishing and fruit collecting, vegetal fibres and other natural products are among the usual sustenance activities. Many turn to breed small herds of goat, sheep and cattle, or work little parcels of land; they may also devote themselves to craftsmanship and various activities related directly or indirectly to tourism. Therefore, we feel that the use of the methodology called Cybercartography (TAYLOR AND LAURIAULT, 2014) will help us to understand the flows and habits in this region, thus contributing to improve the life quality of local communities.
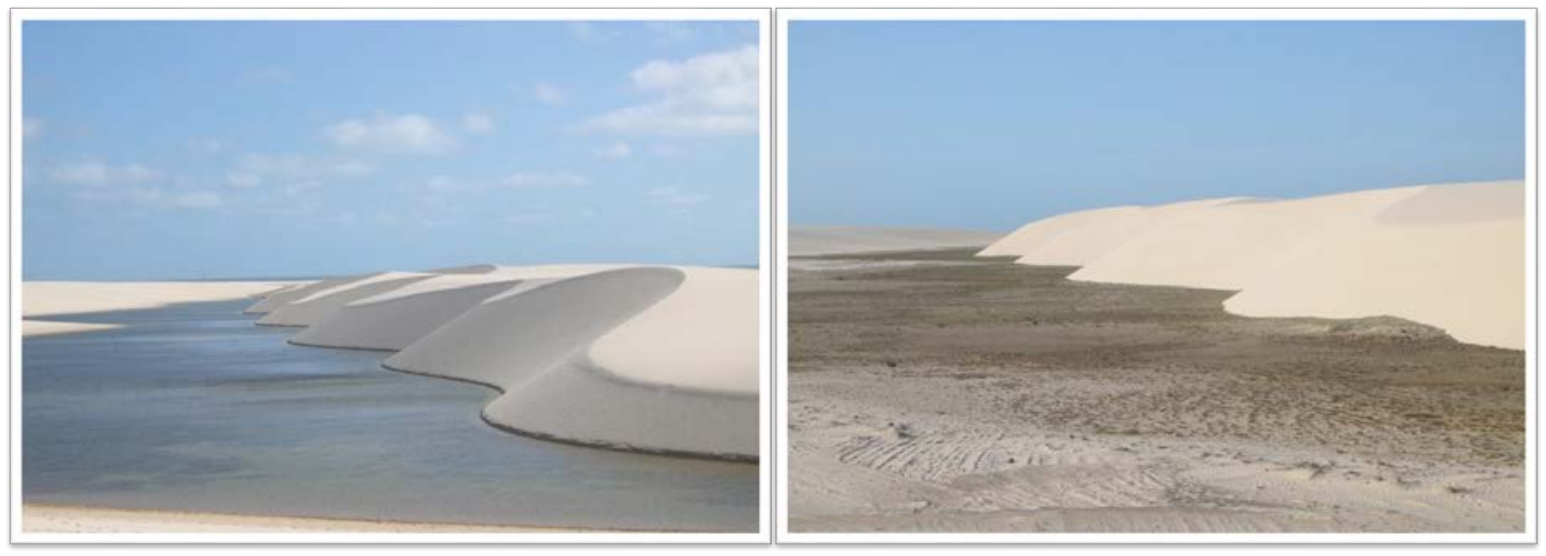

Figure 2. Seasonality of the area, underlined by its two periods: "rainy” and "dry". Source: Souza 2007.

Even if this location is known virtually since the beginning of European occupation, and there exists a National Park established by law in 1981 (BRASIL, 1981), up to this moment there has never been an atlas devoted exclusively to this part of the state of Maranhão. This is, therefore, the first scientific challenge: to create, compile and present maps and texts specifically dedicated to Lençóis Maranhenses, and organized in form of a special regional atlas, showing the socio-environmental dynamics of the place.

Moreover, there is the issue of employing techniques of Cybercartography, specifically of the Nunaliit Cybercartography Atlas Framework (TAYLOR e CAQUARD, 2006). We intend to use this technological platform, designed to create apps of interactive mapping in the internet, using different sources of data and multimedia, which allow users a high degree of participation. By default, the Nunaliit Framework employs a simple and flexible database, founded on documents to store any graphic objects or descriptive attributes (texts). As it happens, virtually in all the directly affected area, and of interest for the atlas project, the regular access to Internet is much reduced or virtually inexistent, even if considering the mobile phone nets.

For this reason, the atlas will be devised in simultaneous versions: a traditional one, in paper print, and also a complementary version created in the Framework for Cybercartographic Atlas. Moreover, the team that developed the Nunaliit platform, led by Professor Fraser Taylor, from the Department of Geography and Environmental Studies and Director of Research Center in Geomatics and Cartography of Carleton University in Ottawa, Canada, has kindly offered to collaborate in this project, supporting the creation of the cybercartographic version, also developing specific apps that allow the elaboration of maps in PDF off-line, which will be then incorporated to the framework of the traditional printed version.

We believe that the availability of the digital version (Cybercartographic) of the Atlas of Lençóis Maranhenses will definitely contribute to the digital inclusion of local communities. With the results reached by this project, we understand that it will be possible to know better the distribution of the communities in the region, their kinds of use and means of production, with emphasis on the handling of natural resources and cultural aspects. Thus, with a better knowledge about the actors in the territory, it is intended to stimulate regional and local actions with respect to environmental education and initiatives of social inclusion.

Therefore, and important objective is to divulge the work and methodology proposed, to incorporate and encourage participation not only of the academic-scientific sector, but also of managers and local population, especially those who live within Lençóis Maranhenses and its area of influence. Thus, this methodological research may be applied to other places in Brazil, for example, with indigenous population, communities of "quilombolas" (descendants of former slaves), "caiçaras" (sea shoreline population) and others. 